\title{
Bringing up the Bodies: Governor Grey's Bone Collecting
}

\author{
JOHN O’LEARY
}

\begin{abstract}
The contributions of Sir George Grey to disciplines as varied as botany, biology, ethnography and linguistics have contributed to his reputation as a humane, liberal-minded imperial functionary. In this context, it is relevant to bring up the contributions which Grey made to anthropology in the shape of the skulls, skeletons and mummified bodies of indigenous peoples that he sent back to scientists in Britain for analysis and display. This article considers what Grey did and why - as far as it is possible to ascertain - he did it. It also suggests that class as well as racial considerations informed Grey's actions. Finally, the article assesses the significance of Grey's bone collecting to the emerging science of anthropology.
\end{abstract}

One of the more contentious issues in society today is the treatment of human remains, especially indigenous human remains. As the near decade-long legal tussle over the bones of Kennewick Man in the United States demonstrated, the issue can become controversial, even when the bones in question belong to the distant past and the genetic link to modern indigenous populations has been disputed. ${ }^{1}$ When the remains are of a more recent date and clearly relate to existing native populations, feelings can run high as the claims of scientists and museum curators clash with those of indigenous peoples and their advocates. Increasingly, as museums and other institutions across the western world recognise both the right to repossess the remains of ancestors and the sometimes unsavoury circumstances in which these were collected, bones and skulls are being returned to indigenous peoples for proper burial or other respectful postmortem treatment. ${ }^{2}$ Newspapers in Australia and New Zealand, for example, now regularly carry stories about ancestral remains of Aboriginal people and Māori "coming home."

This repatriation activity has been complemented by a growing body of scholarly literature on the "body trade," such as Bronwen Douglas and Chris Ballard's Foreign Bodies: Oceania and the Science of Race, 1750-1940. Such studies have examined the collection of indigenous bodies and body parts over the past two or three centuries, locating them in an increasingly racialized anthropological discourse. ${ }^{3}$ The collection of indigenous bodies and body parts emerges in such studies as yet another expression of the "othering" of indigenous peoples - in this case, their reduction to the status of material objects suitable for scientific enquiry. Seen in this light, the return home of ancestral remains alluded to above functions in part as a kind of belated redress for the wrongs of the imperial/colonial past. ${ }^{4}$

In this context, it is relevant to bring up the bone collecting of Sir George Grey, who was governor of several southern-hemisphere British colonies in the middle decades of the nineteenth century. This aspect of Grey's life has received little attention, since biographers of Grey have tended to focus on his political and military career rather than his intellectual interests. Even when those interests have been discussed, there has been little sustained analysis of Grey's contributions to the science of his day, of which his bone collecting was a part. ${ }^{5}$ This article sets out to address this lack, answering a series of questions in the process. What was the historical and cultural context in which Grey's bone collecting took place? What sort of indigenous remains did he collect, and for whom? What, so far as we can tell, were his motivations? Finally, what impact did Grey's bone collecting have on the emerging science of anthropology? 
Grey's bone collecting, which occurred roughly between the 1830 s and the 1860 s, took place at a pivotal time in the development of ethnology, the science that would later come to be called anthropology. In the eighteenth century, skulls of different races had been collected by natural philosophers such as Johann Blumenbach with a view to delineating racial types, while Georges Cuvier, working in the late eighteenth and early nineteenth centuries, had viewed the head as the "surest means of distinction between races." 6 This had led to an increasing focus, especially in France, on the careful measurement of skulls and other bones, with the size and shape of the skull and the brain inside it being taken to indicate mental characteristics such as intelligence. ${ }^{7}$ Data sent back from the periphery of empire in the form of skulls and skeletons of indigenous peoples was deemed especially valuable, as it allowed comparison with European examples, and explorers, soldiers and settlers were often approached to provide specimens. ${ }^{8}$ Many willingly did so, seeing it as part of their duty to the advancement of science. Grey probably saw himself as contributing in this way, though as will be suggested below he may have had other motives, at least at the start. In this respect, as in others, Grey was very much a man of his time.

Grey's activity in this area falls into two distinct parts: an earlier phase, in which he sent indigenous bodies and body parts back to Richard Owen, comparative anatomist and resident conservator of the Hunterian Museum at the Royal College of Surgeons; and a later phase, when he supplied skulls of indigenous peoples to Joseph Barnard Davis, a Staffordshire surgeon and craniometrist who was building up a vast collection of skulls from across the world. The two phases differ somewhat, not merely in chronology, but in the nature of the remains sent back to England, the motivations for sending them, and the uses to which they were put.

The earliest mention Grey makes of his bone collecting is in a letter to Owen written in August 1838, where he mentions that he is sending him "a skeleton of a native of North Western Australia" and notes that "some bits of the skeleton are wanting." "Grey at this time was in the Swan River colony in Western Australia, having just explored the Kimberley region to the north. While his reasons for being there were primarily cartographic, he had a real interest in the flora and fauna of the country he had visited, and the human remains he alludes to were part of a larger consignment of animal specimens he was sending to Owen, specimens that included kangaroo foetuses and "hooded lizards." Such intellectual interests were not unusual in imperial functionaries of the period; Grey, indeed, was joining a long line of army officers and civil servants who studied the natural world and the peoples of the remote territories which they explored or governed. ${ }^{10}$ Grey's interests were more than just pro forma, however; he was genuinely curious about the Aboriginal people he encountered in the Kimberley region and elsewhere in Western Australia, as his Journals of the expedition and later writing on Aboriginal dialects attest. ${ }^{11}$

At the same time, it should be recognized that the practice of sending back specimens to savants in Britain related as much to career ambition on Grey's part as it did to genuine enthusiasm for science - it was a way of raising one's profile, of marking oneself out as intelligent and enlightened. ${ }^{12}$ The young Grey was ambitious, and his despatch of human and animal remains to Owen can be seen as a career move on the part of young man who was "going places."

Owen was evidently happy to correspond with Grey, for six years later, when Grey was governor of South Australia, he wrote to him saying a "dried Mummy of a Native would be most acceptable," adding that he already had "a specimen of a Peruvian in this posture" and 
that he would like "a native similarly crouching" to decorate a vacant pedestal on one side of the entry to the "Small Museum." "I In the same letter Owen mentioned that he had received "some most interesting fossils" from other parts of Australia, including those of Diprotodon, a kind of giant wombat that had become extinct nearly 50,000 years before. Owen, in other words, was receiving all kinds of remains at this time, some younger, some older, some human, some animal. All were part of the giant jigsaw puzzle of how life had developed that he and other scientists were attempting to piece together.

The "Small Museum" Owen alluded to was part of the larger Hunterian Museum at the Royal College of Surgeons, which at this period housed Owen's natural history collections. Judging by his letter, Owen seems to have wanted a mummy primarily as a kind of decorative element, to balance a Peruvian mummy the museum already possessed (in fact, it possessed two, which were the subject of great public curiosity). Owen's request reflected his great interest in the natural history of Australia; it also related to the "mummy mania" that gripped Britain in the 1830s and 1840s. The most famous "mummiologist" of the time was Thomas Pettigrew, who made a handsome living unwrapping Egyptian mummies for fascinated audiences and who published books on the subject. ${ }^{14}$ Pettigrew had been professor of anatomy at Charing Cross Hospital, and it is possible that Owen knew Pettigrew personally; he would certainly have known of his work. Scientific interest apart, a mummy posed at the entrance to his Small Museum was a shrewd move by Owen to raise its profile and attract the public.

Grey obliged Owen's request, noting in a letter written towards the end of the year that he had "sent [Owen] some months since an Australian mummy" which he hoped had "arrived safe" in London, along with "some skeletons of interesting animals." 15 Almost a year later, in 1845, Owen replied at length, thanking Grey for his gift:

I have just received from the British Museum your last acceptable donation for the College Collection, of the skeleton of the Halmaturus Greyi, of the Sphenisens minor, of the Black Cockatoo, and several jaws of sharks. The Mummies of the adult South Australian and child also safely reached us, and keep guard, with the South American Mummy, over the entrance to the Small Museum. The cranial calabashes were extremely interesting, and produced a great sensation amongst the fair auditors, when exhibited and descanted upon at the Zoological Section of the British Association at York! For each and all of these valuable additions to our Museum accept my best thanks: they have an additional value to me as being evidences of your kind \& friendly remembrance, in the midst of your important and numerous duties. ${ }^{16}$

Evidently the "mummy" Grey had promised Owen in his 1844 letter was of a pregnant or nursing mother, possibly of a woman who had died in childbirth. It is striking how in this letter Owen's discussion of these human remains is part and parcel of his larger discussion of animal bodies which Grey had sent back from Australia. Clearly, for Owen, the human identity of these remains was not a matter of concern; they were simply specimens, no more nor less valuable and interesting than the wallaby or the cockatoo he also mentions.

In the same letter, Owen returned to the subject of "the very interesting Australian fossils" he had mentioned before, noting how, as in South America and New Zealand, extinct giant forms were now represented by smaller descendants or relatives. "Those series of facts," he observed, "are very suggestive and interesting." Modern animals, it seemed, constituted remnant populations which had survived the extinction of their giant relatives by being somehow better adapted to their environment. Owen here seems to be speaking about natural selection, a 
foundational concept of the theory of evolution which his colleague Darwin was quietly developing at this period.

Grey and Owen continued their correspondence for a number of years, with Grey sending back specimens from New Zealand, Grey's "last seat of empire," as Owen put it in $1847 .{ }^{17}$ It is possible that these specimens included human remains, though there is no specific mention of these.

Grey's bone collecting for Owen raises questions that many people now find troubling. How old were the skeleton and mummies he went back to Owen? Were they historic, that is, hundreds or even thousands of years old, or were they the remains of the recently dead? How had they been obtained? Had they been discovered accidently, in the course of some other activity, or were they the fruit of grave robbing? ${ }^{18}$

Unfortunately, given the scattering and destruction of anatomical collections that has occurred over the last century and a half-destruction which included the bombing of the Hunterian Museum in 1941 - it is impossible to answer these questions with any certainty. The best we can do is to try to understand what Grey did in the context of the time he lived in. Fortunately, a great deal of scholarly work has been done in this area by science historians and by historians of colonialism, some of whose works are referenced in this article. This work makes clear that Grey's activity proceeded from a certain set of widely held beliefs and assumptions, beliefs and assumptions which were rather different from those we hold today. Notable among them was the idea that Europeans had a right to make use of indigenous bodies and body parts without the consent of their owners or their owners' relatives or descendants. ${ }^{19}$ This idea sprang, in part, from a sense of cultural and racial superiority that had hardened during the course of the nineteenth century, in what one historian has termed "an explosion of race pride." ${ }^{20}$ Grey in fact was not especially racist by the standards of his time; he viewed the Australian Aboriginal people, for example, as being "as apt and intelligent as any other race of men I am acquainted with - they are subject to the same affections, feelings, appetites and passions as other men." 21 He was deeply interested, moreover, in the indigenous cultures he encountered, as his detailed notes and writings, published and unpublished, about Australian Aboriginal peoples and Māori attest, as does his far-sighted patronage of the German philologist Wilhelm Bleek, who helped establish what are now termed Bantu studies and who created a unique written record of the traditional culture of the San (Bushmen) of the Northern Cape. ${ }^{22}$ But Grey certainly believed in the superiority of his own European (specifically Protestant English) civilisation, which he saw as offering indigenous peoples freedom from tyrannical superstition and custom, and the possibility of development. ${ }^{23}$ It is likely that this belief in his own cultural superiority informed his bone-collecting activities.

In addition, Grey would have seen himself as providing important scientific data for natural historians such as Owen, and this conviction may have assuaged any unease he felt about what he was doing, as it did for many bone collectors at this time. ${ }^{24}$ This reduction of indigenous human bodies to the status of specimens was a feature of the European scientific culture of the period; it can be read as evidence of the dehumanising tendency of colonialism and imperialism that many historians have identified. ${ }^{25}$ Grey was, in this respect, very much a man of his era, one which seems in many ways remote from our own. If he felt any guilt at what he was doing, the fact that the bodies in question were unbaptised pagans buried in unconsecrated ground may have helped assuage it, given Grey's fairly traditional Christian beliefs and practice. 
Grey's distance from our modern thought-world is even more striking when consideration is given to Grey's bone collecting for Joseph Davis, which differed in some ways from his earlier bone collecting for Owen. Evidence of Grey's activity in this area is attested to by a dozen or so letters Davis wrote to Grey between 1852 and 1867; no letter of Grey to Davis has survived so far as is known, though he evidently wrote several and no doubt added accompanying notes to the specimens he sent back to England.

In his first letter to Grey, written in 1852, Davis described himself as "extraordinarily desirous of augmenting [his] collection of skulls" before venturing to ask Grey for "any specimens of the different tribes of New Zealanders." ${ }^{26}$ Davis' interest in obtaining a Māori skull sprang from his desire to collect crania from as wide a variety of races as possible, and in fact he corresponded widely with a large number of colonial officials and doctors across the world to this end. ${ }^{27}$

Grey evidently looked kindly on Davis' request, for in a letter written a year later, Davis mentioned Grey's "kind and most obliging letter of May 2" and wrote that he "rejoiced exceedingly" that Grey was inclined to look favourably upon his pursuits and to offer "most valuable assistance" in procuring specimens of skulls. ${ }^{28}$ The rather fawning tone of the letter is typical of Davis, and contrasts with the more matter-of-fact, straightforward language of Owen; it is an index both of Grey's greater importance by this time (New Zealand was his second governorship) and of Davis' comparatively humble status as a country doctor with an amateur interest in craniometry. Grey by this time was no longer "making his way" in the world as an ambitious youngster. Rather, he would have viewed himself as an important imperial functionary setting aside time from a busy schedule to support the advancement of science.

Davis was pleased with the Māori skull Grey sent him, writing in early 1854 that it was a "highly interesting specimen." 29 A few months later he wrote to Grey again, stressing that the skull was of "great interest" to him and asking if Grey might send him other Māori skulls, or those of "other races inhabiting Islands in the Pacific," a region which he regarded as anthropologically "highly interesting." ${ }^{30}$ The next year, perhaps to show his gratitude, Davis sent Grey a proof of an "ancient British cranium, probably of the Brigantes." 31 Why Davis chose this particular example is not clear-possibly it related to the idea (common at the time and which Grey shared) that the situation of Māori was analogous to that of the ancient Britons, who were thought to have benefitted from Roman rule, just as Māori were presumed to be benefiting from British colonisation of New Zealand. ${ }^{32}$

Grey by this time had left New Zealand and had taken up the governorship of the Cape Colony in South Africa. For Davis, this move represented a new opportunity to obtain specimens for his collection, and in his 1855 letter he asked Grey to send him the skulls of the "interesting races" of South Africa, noting that he preferred them undamaged, "and if possible retaining lower jaws" (jaw size and angle relative to the face were important factors for Davis in determining how "advanced" an individual or race was). Once again it appears that Grey responded positively to Davis' request, for two years later, in 1857, Davis wrote that he had received Grey's "kind letter" in which Grey had told him that he had got hold of some "skulls of Bushmen." 33 In the same letter, Davis lamented the "unfavourable circumstances" that had compelled Grey to abandon some "Kaffir crania" (i.e. Bantu skulls) which he had obtained.

What exactly these circumstances were is unclear, but the phrase hints at the difficulty that sometimes attended the collection of human remains, even by individuals as well placed as Grey. This was a problem Davis mentioned several times in his letters to Grey. In a letter 
written in 1856 he had noted enviously how medical officers in the Dutch colonies were "alive" to the importance of obtaining examples of crania of various races, unlike most of their British counterparts. ${ }^{34}$ Two years later he noted approvingly that these Dutch officers "never seem to let a skull escape their hands." ${ }^{35}$ The prohibition in South Africa against the dismemberment or dissection of dead bodies obtained from jails was a source of special frustration for Davis, who lamented in a later letter that the regulation was "far more stringent" than any which prevailed in institutions in Britain, where the Anatomy Act of 1832 had made the bodies of the poor and marginalised available for dissection. ${ }^{36}$ Echoing a popular sentiment among educated people of the period, Davis opined that "if such regulations were strictly observed, there would in great measure be an end put to pathological science, the progress of medicine and surgeryas well as craniology." He then urged Grey to "interfere" so as to procure the rescinding of the regulation, or its modification. ${ }^{37}$ There is no evidence, however, that Grey "interfered" in the way Davis desired.

Davis was very pleased with the Bushman skulls Grey sent him, noting his "great gratification." His 1858 letter is worth quoting at length.

These crania are a great acquisition to me, being the first instalment of South African examples which has come to my collection. I regard them also as of great interest. The strongly marked Bushman character in the little girl's skull, who has not exceeded five years of age, is worthy of observation as showing the innate features of the race. And the striking contrast between the Bushman and the Kaffir skulls is an impressive refutation of Dr Andrew Smith's doctrine, that a Bushman is merely a degenerated Hottentot. I have no doubt whatever that the degeneration, or by whatever name it may be called, the difference dates $a b$ origine. There is a curious passage in Dr Livingstone's recent volume (1) which bears intimately upon this matter. In mentioning the Bakalahari, one of the Bechuana tribes, he alluded to their marked difference from the Bushmen, and says, "living on the same plains with the Bushmen, subject to the same influences of climate, enduring the same thirst, and subsisting on the same food for centuries, they seem to supply standing proof that locality is not always sufficient of itself to account for differences." The passage, as he originally wrote it, is in a letter to Sir Roger Murchison, which I heard read at Cheltenham, was even much stronger than this. No time can eradicate the essential characteristics of races, which are totally independent of external influences. ${ }^{38}$ 


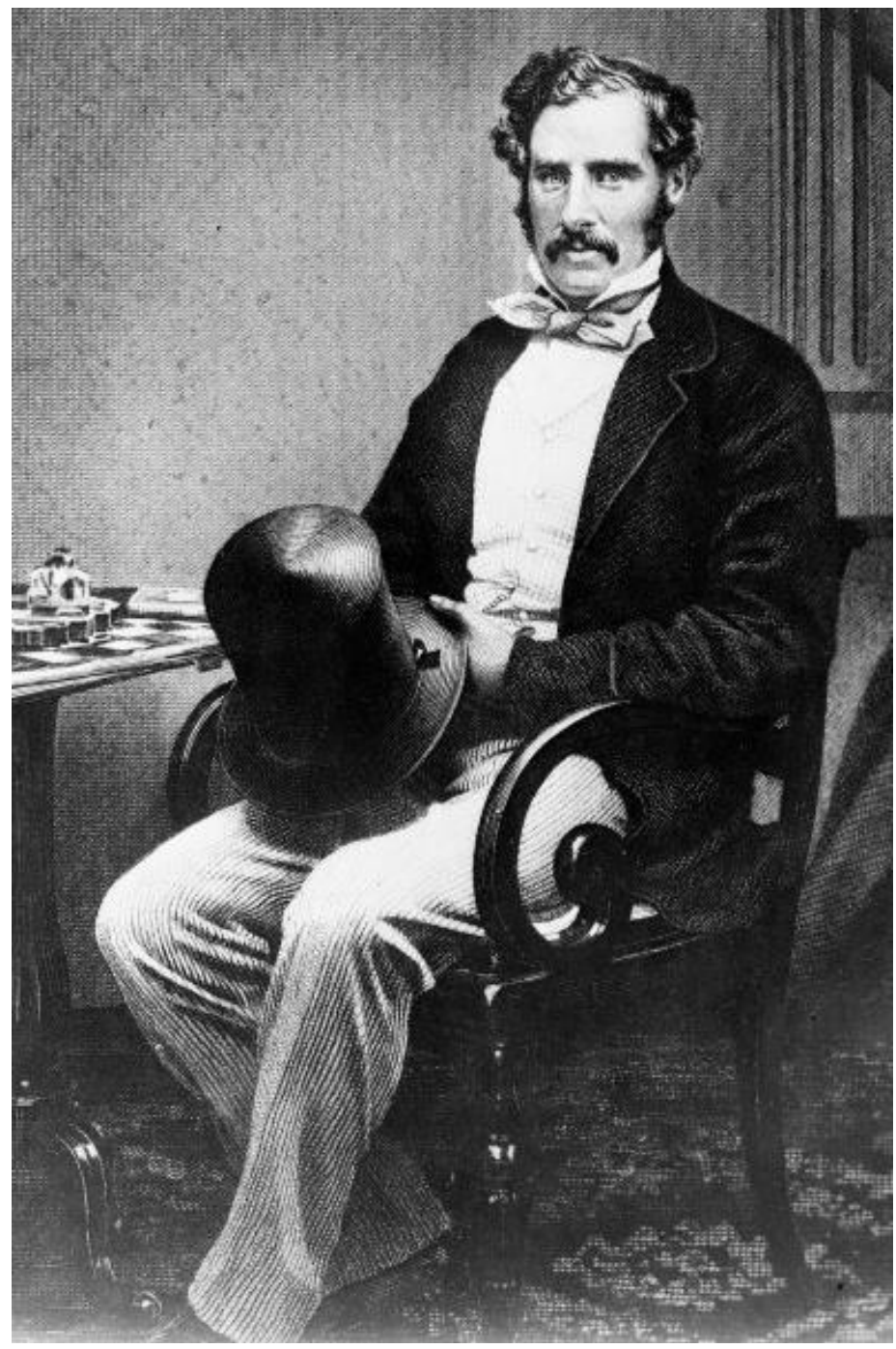

Figure 1. Sir George Grey, c. 1861. At this period, he was sending skulls from South Africa to Joseph Davis in England. (Photograph: Sir George Grey Special Collections, Auckland Libraries, 7-A3953, no known copyright.)

The marked differences between the Bushman and Kaffir (Bantu) skulls were evidence, Davis thought, that the two races had separate origins — proof that humankind had not evolved from a single ancestor, as the Biblical account of creation suggested and as many contemporary ethnologists believed. ${ }^{39}$ Polygenism was, however, controversial and Davis (careful to foster his relationship with Grey) asked the governor to "excuse my dilating upon a subject upon which you may see much reason to differ from me in your views." He ended his letter with the hope that Grey would accept his volumes of Crania Britannica, an encyclopaedic survey of British skulls from all periods which he had begun publishing two years earlier.

Davis corresponded with Grey for several more years. His last letter dates from December 1867, by which time Grey had returned to New Zealand. As usual, he asked Grey for human remains - specifically for "the bones of a Maori" which should be "complete and adult" so that he could have them articulated. His brother-in-law, he noted, had acquired the bones of a male and female Aboriginal, of which he had made "two beautiful skeletons." 
writing to Grey after this date is unclear; maybe he felt he had enough specimens, for by this time he had one of the largest collections of its kind in Britain. ${ }^{41}$ In the same year, he published a catalogue of his collection, titled Thesaurus Craniorum. Later, the collection was bought by the Royal College of Surgeons, where Richard Owen, Grey's old correspondent, had been a professor and curator.

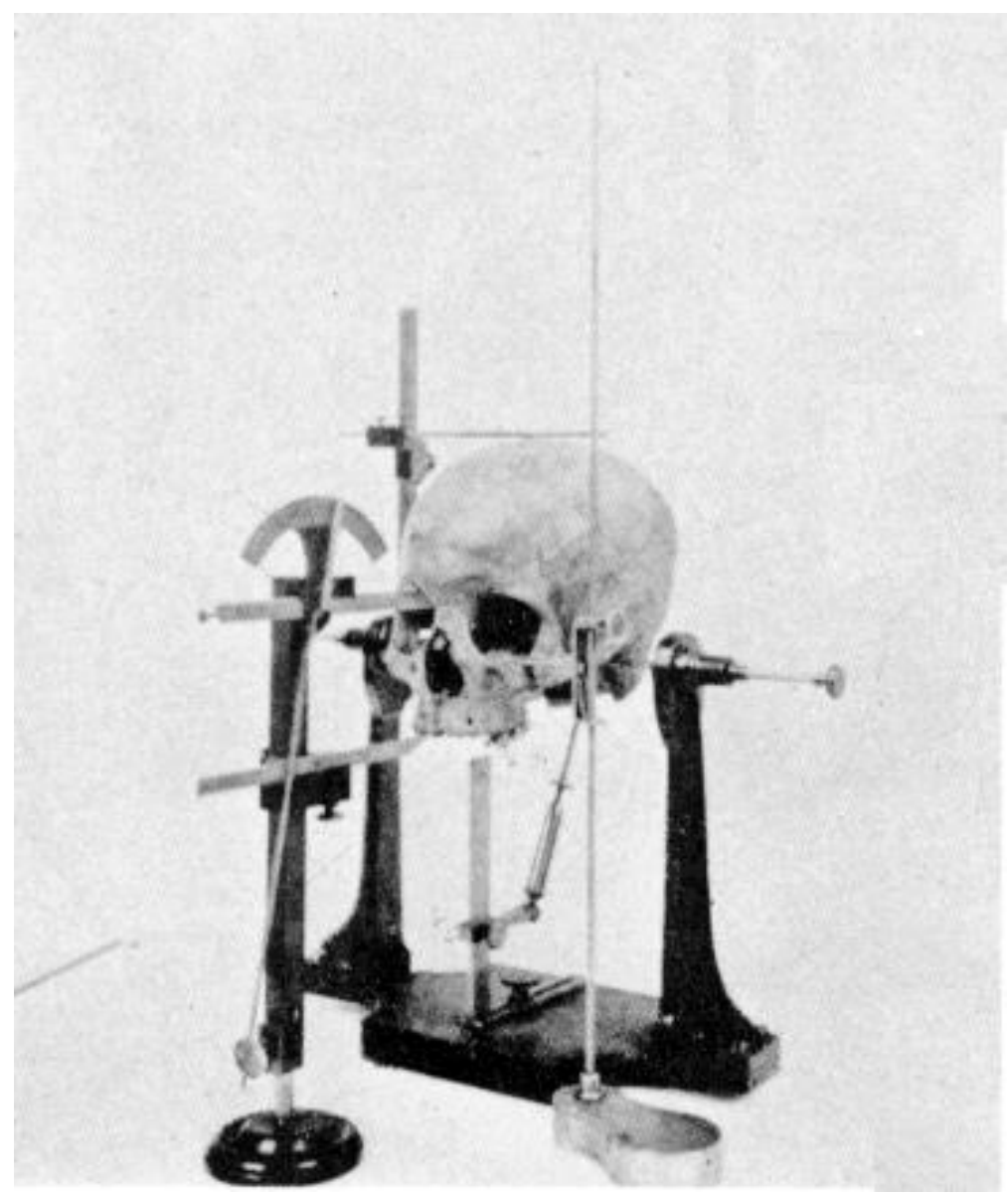

Figure 2. Skull and craniometric apparatus. (Photograph reprinted from C. Fawcett and A. Lee, "A Second Study of the Variation and Correlation of the Human Skull," Biometrika 1, no. 4 [Aug 1902], 408-67, plate IV, titled there "Figure 2. Craniphor, Goniophor, and Scriber."

Image is in the public domain.)

Since the Grey side of this correspondence has not yet been found (if it still exists), it is hard to assess exactly how Grey viewed Davis and his requests for skulls and skeletons. Clearly, he had some interest in what Davis was doing and presumably saw it as having some value; at the same time, it should not be assumed that he necessarily accorded craniology the same high importance as Davis did. As a letter to Grey from John Crawfurd, a Scottish physician and Asian linguist, attests, not everyone was convinced by the science:

To be plain with you, although I should not like to be so frank with my friend Dr Davis, I do not think that much will ever come of his pet study. The whole science (if it be one) of Ethnology is so full of perplexity that one is lost in attempting to unravel it. That there are and that there always have been many distinct races of man, no one can doubt that looks at an European and a Negro, a Hottentot and a Hindu, but then some of the races approximate so nearly and there has been, in the civilised parts of the world so much conmixture, that you are completely baffled in attempting to 
distinguish them. There is a great deal in the study, but the Ethnologist make too much of it. Mr Owen told me that when arranging by races the skulls in the Museum of the College of Surgeons, he placed one skull among the African but turning it up, he saw it labelled "Skull of a Scots Sergeant killed at Waterloo"! ${ }^{42}$

Perhaps in this, as in many other respects, Grey kept an open mind, seeing himself as a collector and transmitter of data rather than as a savant coming to settled conclusions about a subject as complex as racial origins. This capacity for intellectual openness, for entertaining a range of ideas and possibilities, is one of Grey's more striking features.

Grey's bone collecting for Davis raises even more questions than his bone collecting for Owen, for as the correspondence with Davis reveals, the skulls Davis wanted were not ancient or historic but fresh, or fairly fresh. While Grey as governor of a Crown colony is unlikely to have engaged in body snatching himself, he may have obtained his skulls from local collectors who had fewer scruples, making him complicit, if at a remove. If he had qualms about what he was doing, he may have assuaged them by the thought that he was providing a service to science, specifically to craniology but more broadly to anthropology. This was an area in which Grey had a considerable, longstanding interest; as early as 1837 in a letter to Richard Owen he had expressed the hope that his researches might prove useful in any inquiry into the "origin and dissemination of the different races of men." 43 Grey, in other words, was in search of human origins. This search - the deep and abiding leitmotiv of Grey's intellectual life-encompassed domains as different as philology, indigenous orature, archaeology and anthropology. Anything he could find-whether words, or legends, or stone tools, or skulls-which helped elucidate these origins was grist to the research mill. ${ }^{44}$ Moral qualms were either set aside, or not entertained in the first place.

As noted above, this reduction of indigenous people's body parts to the status of specimens can be read as evidence of the dehumanising tendency of colonialism and imperialism. It should be remembered, however, that at this period British bodies, too, were regularly bought and sold, shipped and traded, often for use in anatomy schools. ${ }^{45}$ The indigenous human remains which Grey sent back to Davis were not treated much differently, in other words, from those of the British poor and marginalised if they had the misfortune to die in the poorhouse or prison. ${ }^{46}$ Class at home and race in the colonies were the operating factors in how a body was treated and used after death. But even in the colonies class could obtrude, for it was the bodies of poor and marginalised indigenes (rather than those of indigenous aristocrats, for example) which tended to be exhumed, dissected and exported, as a reference in a letter of Davis to the possibility of obtaining the body of an elderly Bushman, executed for murder, suggests. ${ }^{47}$ The operating dynamic was, fundamentally, one of status - those who had it could ensure their remains (and those of their relatives and ancestors) were treated with respect, while those who did not could not.

Before concluding, it is worthwhile to try to assess how important, scientifically speaking, Grey's bone collecting was. As noted above, the skulls and skeletons that Grey collected were part of a larger imperial research exercise that saw Grey (and other colonial explorers, officials and settlers) despatch human bodies and body parts to scientists in Britain for analysis and storage in the era's new museums, institutes and private collections. This in turn was part of an even larger gathering of scientific data of all kinds from across the British Empire (and, sometimes, from beyond it) that characterised the early and middle decades of the nineteenth century as emerging disciplines such as anthropology demanded increasing quantities of information relevant to their burgeoning fields of enquiry. ${ }^{48}$ Grey was active in providing a 
variety of data of this kind - skulls and skeletons were merely one type of material he forwarded to the imperial centre. ${ }^{49}$

In this flood of material, not all consignments were of equal value, scientifically speaking, and not all were subject to rigorous scientific analysis - the mummified remains of the mother and child that Grey sent back to Owen early in his career were viewed by the latter, it seems, primarily as a decorative element, though it is possible that their scientific value was later recognised. In the case of the skulls that Grey sent back to Davis, the situation is somewhat different; these were analysed and stored for future reference and can be seen, therefore, as having made a contribution to craniology and, arguably, to anthropology, albeit to an anthropology of a racialized kind that many people these days find troubling. Perhaps it is best to view Grey's bone collecting as a kind of footnote in the history of science, not hugely significant but of interest nevertheless, especially for what it tells us about Grey and his beliefs and assumptions.

Grey's bone collecting, as noted earlier, forms a little-discussed aspect of his intellectual activity. It suggests that Grey's reputation for enlightened humanity-a reputation which he carefully fostered in publications such as his Journals - should not be accepted uncritically. This is a proposition which historians are increasingly exploring as a newer, more ideologically driven approach to evaluating the past makes itself felt; Leigh Dale, for example, suggests that naïve admiration for Grey and his achievements carries as many risks as unqualified condemnation, and even goes so far as to find a "repellent sense of superiority and distance" in certain passages where he writes about indigenous peoples. ${ }^{50}$ Many scholars will reject this diagnosis, however, pointing to passages where they claim he evinces considerable empathy and compassion. ${ }^{51}$ In the end, it is wisest perhaps to conclude when bringing up the subject of the bodies which Grey collected that he was, simply, a man of his time and that he exhibited many of the beliefs and assumptions of the period, beliefs and assumptions that many of us now find troubling. These beliefs and assumptions were not original or unusual; on the contrary, they were very much those of the mid-Victorian establishment to which Grey belonged. They remind us that Grey - who in some respects can seem quite modern, quite "like us"-is in other respects rather distant: a man from another age.

John O'Leary researches nineteenth-century colonial and imperial culture. He is currently writing a book about Sir George Grey's intellectual life.

\footnotetext{
${ }^{1}$ See Christine Quigley, Skulls and Skeletons: Human Bone Collections and Accumulations (Jefferson, NC: McFarland, 2001), 218-220.

${ }^{2}$ Quigley, Skulls and Skeletons, 217, 225.

${ }^{3}$ See Bronwen Douglas, "Introduction," in Foreign Bodies: Oceania and the Science of Race 1750

1940, ed. Bronwen Douglas and Chris Ballard (Canberra: ANU Press, 2008), 5.

${ }^{4}$ See Tiffany Jenkins, Contesting Human Remains in Museum Collections: The Crisis of Cultural Authority (London and New York: Routledge, 2011), 16-17.

${ }^{5}$ See for example Edmund Bohan, To Be a Hero: A Biography of Sir George Grey (Auckland: HarperCollins, 1998), which briefly discusses Grey's contributions to learning (60, 198-99, 242).

${ }^{6}$ See Bronwen Douglas, "Novus Orbis Australis: Oceania and the Science of Race 1750-1850," in

Douglas and Ballard, eds., Foreign Bodies, 109.

${ }^{7}$ See Douglas, "Novus Orbis Australis," 109-10.
} 
${ }^{8}$ For a discussion of this in an Australian context, see Paul Turnbull, "British Anthropological Thought in Colonial Practice: The Appropriation of Indigenous Australian Bodies," in Douglas and Ballard eds., Foreign Bodies, 214-19.

${ }^{9}$ George Grey to Richard Owen, 19 August 1838, MS Papers 0705/4, Alexander Turnbull Library, Wellington.

${ }^{10}$ See Zoe Laidlaw, Colonial Connexions 1815-1845: Patronage, the Information Revolution and Colonial Government (Manchester: Manchester University Press, 2005), 31.

${ }^{11}$ See Bohan, To Be a Hero, 29-30, 31, 33, 43.

${ }^{12}$ See Laidlaw, Colonial Connexions, 33.

${ }^{13}$ Richard Owen to George Grey, 27 July 1844, GL O10.2, Grey Collection, Auckland Library.

${ }^{14}$ For a full discussion of Pettigrew, see Gabriel Moshenska, "Unrolling Egyptian Mummies in

Nineteenth-Century Britain," British Journal for the History of Science 47, no. 3 (2014): 451-77.

${ }^{15}$ George Grey to Richard Owen, 17 December 1844, MS Papers 0205/7, Alexander Turnbull

Library, Wellington.

${ }^{16}$ Richard Owen to George Grey, 7 November 1845, GL O10.3, Grey Collection, Auckland Library.

${ }^{17}$ Richard Owen to George Grey, 19 January 1847, GL O10.4, Grey Collection, Auckland Library.

${ }^{18}$ Grey may have been involved in grave robbery, as the activity of John Lort Stokes, a naval lieutenant and close contemporary who extracted Aboriginal remains from a burial site in the Kimberley region of Australia, suggests. Stokes, too, sent a skeleton back to the Royal College of Surgeons (possibly to Owen), suggesting that Grey's bone collecting for Owen at this period was by no means unique or unusual. See Paul Turnbull, "Indigenous Australian People, Their Defence of the Dead and Native Title," in The Dead and Their Possessions: Repatriation in Principle, Policy and Practice, ed. Jane Hubert and Cressida Fforde (London and New York: Routledge, 2002), 70.

${ }^{19}$ See Jane Hubert and Cressida Fforde, "Introduction," in Hubert and Fforde, eds., The Dead and Their Possessions, 13.

${ }^{20}$ See Bronwen Douglas, "Climate to Crania: Science and the Racialization of Human Difference," in Douglas and Ballard, eds., Foreign Bodies, 73.

${ }^{21}$ See George Grey, Journals of Two Expeditions of Discovery in North-West and Western Australia during the Years 1837, 1838 and 1839, vol. 2 (London: T. and W. Boone, 1841), 374.

${ }^{22}$ See Andrew Bank, Bushmen in a Victorian World: The Remarkable Story of the Bleek-Lloyd Collection of Bushman Folklore (Cape Town: Double Story, 2006), 26-31.

${ }^{23}$ For a detailed discussion of Grey's views on indigenous peoples and their cultures, see Bernard Cadogan, "A Terrible and Fatal Man": Sir George Grey and the British Southern Hemisphere (Wellington: VUW TOWRU, 2014), 92-112.

${ }^{24}$ See Hubert and Fforde, "Introduction," 27.

${ }^{25}$ Hubert and Fforde, "Introduction," 29.

${ }^{26}$ Joseph Davis to George Grey, 24 August 1852, GL D11.1, Grey Collection, Auckland Library, New Zealand.

${ }^{27}$ See Turnbull, "British Anthropological Thought," 220.

${ }^{28}$ Joseph Davis to George Grey, 27 August 1853, GL D11.2, Grey Collection, Auckland Library, New Zealand.

${ }^{29}$ Joseph Davis to George Grey, 13 January 1854, GL D11.3, Grey Collection, Auckland Library, New Zealand.

${ }^{30}$ Joseph Davis to George Grey, 17 May 1854, GL D11.4, Grey Collection, Auckland Library, New Zealand.

${ }^{31}$ Joseph Davis to George Grey, 20 May 1855, GL D11.5, Grey Collection, Auckland Library, New Zealand.

${ }^{32}$ See George Stocking, Victorian Anthropology (London and New York: Free Press, 1987), 87.

${ }^{33}$ Joseph Davis to George Grey, 27 June 1857, GL D11.7, Grey Collection, Auckland Library, New Zealand.

${ }^{34}$ Joseph Davis to George Grey, 12 November 1856, GL D11.6, Grey Collection, Auckland Library, New Zealand.

${ }^{35}$ Joseph Davis to George Grey, 6 June 1858, GL D11.9, Grey Collection, Auckland Library, New Zealand. 
${ }^{36}$ See Ruth Richardson, Death, Dissection and the Destitute (Harmonsworth: Penguin, 1988), 259.

${ }^{37}$ Joseph Davis to George Grey, 5 January 1859, GL D11.10, Grey Collection, Auckland Library, New Zealand.

${ }^{38}$ Joseph Davis to George Grey, 5 March 1858, GL D11.8, Grey Collection, Auckland Library, New Zealand.

${ }^{39}$ See Turnbull, "British Anthropological Thought," 205-06.

${ }^{40}$ Joseph Davis to George Grey, 12 December 1867, GL D11.13, Grey Collection, Auckland Library, New Zealand.

${ }^{41}$ See Turnbull, "British Anthropological Thought," 219.

42 John Crawfurd to George Grey, 3 June 1857, GL C59.4, Grey Collection, Auckland Library, New Zealand.

${ }^{43}$ George Grey to Richard Owen, 22 July 1837, Add. 42583 ff. 125, British Library, London.

${ }^{44}$ For a fuller discussion of Grey's intellectual activities, see George Stocking, Victorian Anthropology, 81-87.

${ }^{45}$ See Richardson, Death, Dissection and the Destitute, 72.

${ }^{46}$ See Hubert and Fforde, "Introduction," 3.

${ }^{47}$ See Joseph Davis to George Grey, 5 January 1859, cited above. In his letter, Davis notes his regret that the body of "Old Coert," executed for the murder of his wife, had not been made available for dissection by a local South African doctor.

${ }^{48}$ See Laidlaw, Colonial Connexions, 31-35.

${ }^{49}$ For example, Grey also collected ancient stone tools from New Zealand and South Africa. In 1869, he exhibited "quartzite implements" from South Africa at the Ethnological Society in London.

${ }^{50}$ See Leigh Dale, "George Grey in Australia, New Zealand and South Africa," in Writing, Travel and Empire: In the Margins of Anthropology, ed. Peter Hulme and Russell McDougall (London and New York: Tauris, 2007), 26-27, 35-36.

${ }^{51}$ See for example Bohan, To Be a Hero, 27, 42-43, 49. 